\title{
Rural and Central City Residents with Multiple Children Likely to Be Hardest Hit by Proposed WIC Cuts
}

JESSICA A. BEAN

$\mathrm{O}$ n June 14, 2011, the U.S. House of Representatives passed an Agriculture Appropriations bill, setting fiscal year (FY) 2012 funding for a variety of nutrition programs, including the Special Supplemental Nutrition Program for Women, Infants, and Children (WIC). Although the allocated funds are higher than originally proposed, the FY 2012 funding is $\$ 733$ million less than FY 2011 levels, and far less than what is needed to serve all who are eligible. ${ }^{1}$ According to the Center on Budget and Policy Priorities, this cut would force WIC administrators to turn away 300,000 to 450,000 eligible women, infants, and children next year. ${ }^{2}$ The Senate has not yet developed its Agricultural Appropriations Bill.

WIC is a nutrition program that serves pregnant or postpartum women, infants, and children up to age 5 (who meet certain criteria) by providing them with nutrition education and checks or vouchers for food purchases. ${ }^{3}$ Foods eligible for WIC are high in certain nutrients and are designed to meet the special nutritional needs of low-income pregnant, breastfeeding, or postpartum women, as well as infants and children who are at risk for poor nutrition. ${ }^{4}$ Preliminary estimates from the Food and Nutrition Service show that WIC has served an average of 8.9 million participants (women, infants, and children) each month in FY 2011 (data available from October 2010 to March 2011). ${ }^{5}$ More than threequarters (77 percent) of these participants are infants and children, with women making up the remaining 23 percent. ${ }^{6}$

This brief uses data from the 2007 and 2010 Current Population Survey's (CPS) Annual Social and Economic Supplement (ASEC) ${ }^{7}$ to describe the distribution of WIC receipt across the population and to detail place-based differences in receipt. The results will help policymakers and service providers to better understand the population likely affected by cuts to WIC funding.

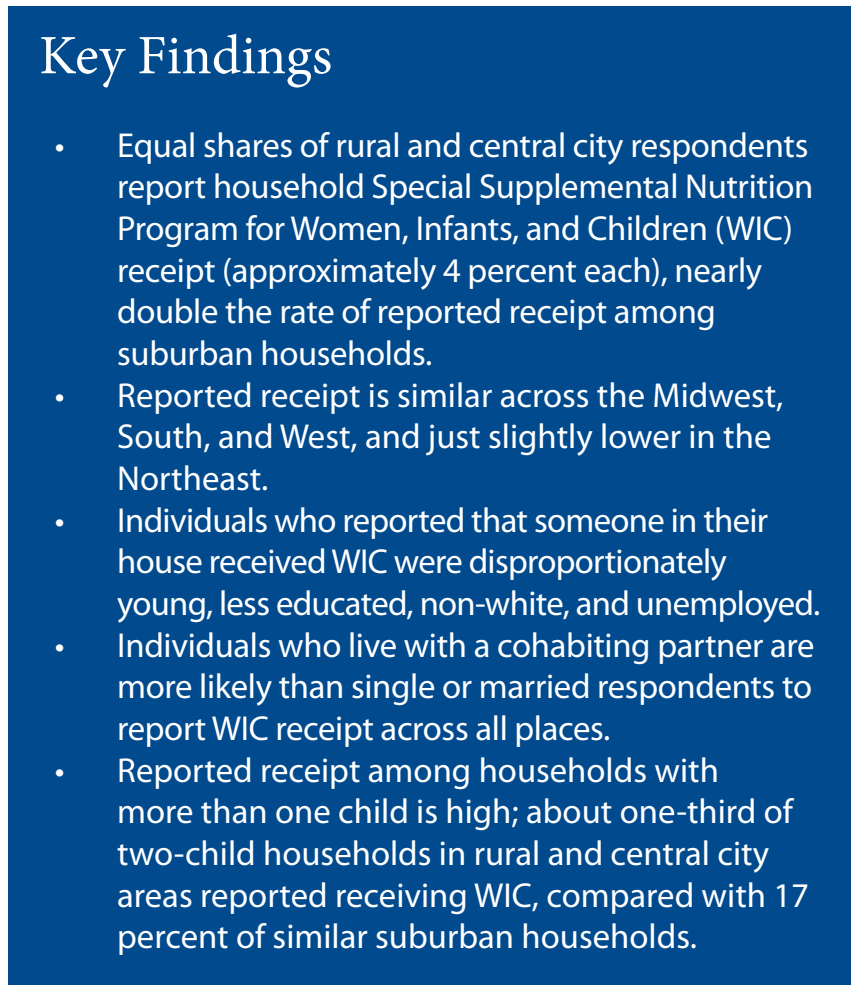

\section{Place-Based Differences in Reported WIC Receipt}

In 2010, 4 percent of respondents in rural and central city areas reported that someone in their household received WIC. This compares with just over 2 percent of suburban respondents (see Table 1). Receipt was equally prevalent in the Midwest, South, and West, and slightly lower in the Northeast. Since the recession began in 2007, WIC receipt significantly increased only in central cities (by 3.6 percentage points). ${ }^{8}$ 
TABle 1. Characteristics of Households

RECEIVING WIC IN $2010^{1}$

\begin{tabular}{|c|c|c|c|}
\hline & Rural & Suburban & Central City \\
\hline $\begin{array}{l}\text { Distribution of WIC Recipients } \\
\text { Income }^{2}\end{array}$ & $3.9^{\mathrm{a}}$ & $2.2^{c}$ & 4.0 \\
\hline$<100 \%$ of $\mathrm{FPL}$ & $12.7^{\mathrm{a}}$ & $9.9^{c}$ & 12.9 \\
\hline $100-200 \%$ of FPL & 5.3 & $5.0^{c}$ & 6.3 \\
\hline $\begin{array}{l}>200 \% \text { of FPL } \\
\text { Number of Children Under } 6\end{array}$ & $1.0^{\mathrm{a}}$ & $0.5^{c}$ & 0.9 \\
\hline None & $0.9^{\mathrm{a}}$ & $0.6^{c}$ & 1.0 \\
\hline One & $21.7^{\mathrm{a}, \mathrm{b}}$ & $10.5^{c}$ & 18.7 \\
\hline Two & $33.1^{\mathrm{a}}$ & $17.2^{c}$ & 31.6 \\
\hline $\begin{array}{l}\text { Three or more } \\
\text { Region }\end{array}$ & $47.2^{\mathrm{a}}$ & $23.1^{c}$ & 35.1 \\
\hline Northeast & $2.7^{\mathrm{a}}$ & $1.3^{c}$ & 3.0 \\
\hline Midwest & $3.8^{\mathrm{a}, \mathrm{b}}$ & $1.8^{\mathrm{C}}$ & 4.9 \\
\hline South & $4.3^{\mathrm{a}}$ & $2.4^{c}$ & 4.0 \\
\hline $\begin{array}{l}\text { West } \\
\text { Marital Status }\end{array}$ & 3.9 & $3.3^{c}$ & 4.0 \\
\hline Married & $3.3^{\mathrm{a}, \mathrm{b}}$ & $2.1^{\mathrm{c}}$ & 4.6 \\
\hline Cohabiting & $10.6^{\mathrm{a}}$ & $6.6^{c}$ & 9.0 \\
\hline Single & $3.5^{\mathrm{a}, \mathrm{b}}$ & $1.8^{\mathrm{c}}$ & 2.9 \\
\hline Age & & & \\
\hline $18-24$ & $20.0^{\mathrm{a}, \mathrm{b}}$ & 10.7 & 11.3 \\
\hline $25-36$ & $11.2^{\mathrm{a}, \mathrm{b}}$ & $5.4^{c}$ & 8.2 \\
\hline $37-45$ & 3.6 & 2.8 & 3.7 \\
\hline Over 45 & 0.8 & $0.5^{c}$ & 1.1 \\
\hline Employment Status & & & \\
\hline Employed & $3.5^{\mathrm{a}}$ & $1.9^{c}$ & 3.7 \\
\hline Unemployed & $9.5^{\mathrm{a}}$ & 6.0 & 7.3 \\
\hline $\begin{array}{l}\text { Not in Labor Force } \\
\text { Education }\end{array}$ & $3.6^{\mathrm{a}}$ & $2.2^{\mathrm{c}}$ & 3.9 \\
\hline Less than high school & $5.7^{\mathrm{b}}$ & $7.0^{c}$ & 10.0 \\
\hline High School & $4.3^{\mathrm{a}}$ & $2.8^{c}$ & 5.0 \\
\hline Some college & $4.0^{\mathrm{a}}$ & $1.9^{c}$ & 4.0 \\
\hline College graduate & $1.1^{\mathrm{a}}$ & $0.6^{c}$ & 0.8 \\
\hline Race & & & \\
\hline White, non-Hispanic & $3.0^{\mathrm{a}, \mathrm{b}}$ & 1.2 & 1.3 \\
\hline Black, non-Hispanic & $7.0^{\mathrm{a}}$ & $3.9^{c}$ & 6.2 \\
\hline Other, non-Hispanic & $9.3^{\mathrm{a}, \mathrm{b}}$ & 2.3 & 2.6 \\
\hline Hispanic & 9.5 & $8.0^{c}$ & 10.0 \\
\hline
\end{tabular}

Note: Estimates from the Current Population Survey's 2010 Annual Social and Economic Supplement. All data are weighted.

1. Characteristics refer to householder. All estimates restricted to householders aged 18 or older.

2. Income categories are mutually exclusive.

a. Rural and suburban comparison statistically significant at $p<0.05$.

b. Rural and central city comparison statistically significant at $p<0.05$.

c. Suburban and central city comparison statistically signficant at $p<0.05$.

\section{Who Receives WIC?}

WIC receipt is most prevalent among "disadvantaged" populations, suggesting that WIC is effectively reaching its target population. Among the youngest respondents (those aged 18 to 24), one-fifth living in rural areas reported that someone in their household received WIC, significantly higher than the 11 percent of young suburban and central city respondents reporting the same. One in ten central city respondents with no high school diploma reported WIC receipt, substantially higher than the rates among rural and suburban households with similar education levels (6 and 7 percent, respectively). Respondents with only a high school diploma were the next most likely to receive WIC in all locales, although in rural areas, those with some college were just as likely to report WIC receipt as those with just a high school degree. As might be expected owing to the link between education and income, those with a college degree were least likely (approximately 1 percent) to report household WIC receipt.

In rural, suburban, and central city locales, white respondents were least likely to report that someone in their household received WIC, although receipt among white respondents was highest in rural areas (likely a reflection of the larger white population there). In rural areas, all nonwhite respondents were similarly likely to report receiving WIC, though in suburban and central city areas, rates were highest among Hispanic respondents.

As might be expected, respondents who were unemployed were substantially more likely to report WIC receipt than were working respondents. However, in rural and central city areas, nearly 4 percent of employed respondents reported receiving WIC compared with just 2 percent of employed suburban respondents. Reported receipt among those not in the labor force (that is, those who are voluntarily not working, or who have dropped out of the labor force) was identical to those who were employed across all places. This finding likely reflects the fact that some in this group may be more financially secure than the unemployed, perhaps allowing them to intentionally take time out of the workforce. Finally, as also might be expected given the recession, between 2007 and 2010 both the decline in the share of WIC recipients who were employed and the increase in the share who were unemployed were significant. ${ }^{9}$

\section{Family Structure Differences}

Fewer than 1 percent of households with no children reported WIC receipt (these households may include a pregnant woman). Respondents with two children were more likely to report WIC receipt than were those with one child, across all places. ${ }^{10}$ However, respondents with three or more children were no more likely to report receipt than those with two children, except in rural places. In 
rural places nearly half (47.2 percent) of rural households with three or more children reported receiving WIC. This compares with 33.1 percent of rural two-child households. Overall, reported WIC receipt among multiple-child households is quite high. More than one-third of central city households with three or more children reported receiving WIC, and nearly one-fourth of similar suburban households reported the same.

Across all places, respondents who live in cohabiting relationships are most likely to report someone in the household receiving WIC. Nearly 11 percent of rural cohabitors report WIC receipt, statistically similar to the 9 percent of central city cohabitors, but higher than the 6.6 percent of cohabiting suburban households. In rural areas, single respondents reported WIC receipt at rates similar to married respondents, at just over 3 percent. ${ }^{11}$ In suburban and central city areas, however, receipt among single respondents was substantially lower than among married respondents.

In summary, rural and central city families are most likely to rely on WIC, but especially these areas' most vulnerable families. These families include the poor, the young, the less educated, minorities, the unemployed, cohabitors, and those with multiple children. While most of these findings are not unexpected, as they are WIC's target population, it is important to note that the program seems to be reaching the families it aims to serve. Programs like WIC become particularly important for vulnerable families in a struggling economy against a background of other financial challenges.

\section{Implications of Cuts to the WIC Budget}

For fifteen years, there has been consensus by Administrations and Congresses of both parties to provide enough WIC funding so that no eligible applicants would be turned away. ${ }^{12}$ Now that commitment is in question. Negotiations currently underway to reduce the federal deficit are likely to include an overall cap on all federal appropriations. Any agreement will have implications for discussions of WIC funding levels. Stricter limits on appropriations will increase the pressure on WIC funding.

According to the Food and Nutrition Service (FNS), WIC is "one of the nation's most successful and cost-effective nutrition intervention programs." ${ }^{13}$ The FNS cites nearly two dozen studies that find that WIC improves pre- and postnatal outcomes; helps lower certain nutritional deficiencies; improves access to prenatal care, regular medical care, and immunizations; and encourages early cognitive development in children. ${ }^{14}$ However, unlike the Supplemental Nutrition Assistance Program (SNAP, formerly known as food stamps) and reduced price/free school lunches, WIC is not an entitlement program. ${ }^{15}$ That is, when funds run out, women and children are placed on a waiting list, with no guarantee of ever being served. In addition to fewer dollars allocated for food, reduced WIC funding could also result in administra- tive cuts, meaning WIC agencies could be open fewer hours and have fewer educators on staff, leading to reduced access and poorer outcomes for all participants. ${ }^{16}$ As nutrition education and a quality diet have lifelong benefits, cuts to WIC funding could result in higher societal costs in the future. ${ }^{17}$

\section{Data}

This brief uses data from the U.S. Census Bureau's Current Population Survey's (CPS) Annual Social and Economic Supplement conducted in March 2007 and March 2010. The CPS provides a nationally representative sample of approximately 50,000 households and the individuals in those households, and collects demographic, economic, and employment information, as well as participation in select government assistance programs. The analyses here are limited to responses from householders only. Comparisons presented in the text are statistically significant at the 0.05 level.

\section{E N D N O T ES}

1. Zoë Neuberger and Robert Greenstein, "House WIC Cuts Would End Food Assistance for 300,000 to 450,000 LowIncome Women and Children," June 23 Memo (Washington, DC: Center on Budget and Policy Priorities, 2011). Available at http://www.cbpp.org/files/5-23-11fa.pdf.

2. Zoë Neuberger, "Claim Regarding High WIC Administrative Costs Is False," June 23 Memo (Washington, DC: Center on Budget and Policy Priorities, 2011). Available at http:// www.cbpp.org/files/6-14-11fa.pdf.

3. To be eligible for WIC, an applicant's pre-tax income must be at or below 185 percent of the federal poverty line, and the applicant must be a state resident and be determined to be nutritionally at-risk by a healthcare provider. See Food and Nutrition Service, "Frequently Asked Questions about WIC" (Washington, DC: U.S. Department of Agriculture, 2011). Available at http://www.fns.usda.gov/wic/faqs/faq.htm\#3.

4. Eligible foods include breakfast cereal, infant cereal/ fruits/vegetables/meat (i.e. "baby food"), infant formula, milk, cheese, tofu, soy milk, beans, peanut butter, fruits and vegetables, canned fish, whole grain breads, juice, eggs, and medical foods (for those with special dietary needs). See Food and Nutrition Service, "WIC Eligible Foods" (Washington, DC: U.S. Department of Agriculture, 2010). Available at http://www.fns.usda.gov/wic/benefitsandservices/ foodpkgregs.htm\#WIC-ELIGIBLE_MEDICAL_FOODS_.

5. Fiscal Year 2011 began October 2010; data available through March 2011. See Food and Nutrition Service, "Program Data: WIC Agency Level Monthly Spreadsheets, May 27" (Washington, DC: U.S. Department of Agriculture, 2011). Available at http://www.fns.usda.gov/pd/wicmain.htm. 
6. Ibid.

7. The CPS questionnaire asks respondents whether "At any time in the last year, (were you/was anyone in this household) on WIC, the Women, Infants, and Children Nutrition program?" Therefore, "WIC receipt" as examined in this brief is self-reported from a single household respondent. An acknowledged limitation of the data is the risk of underreporting if the respondent is unaware of other household members' WIC receipt.

8. Carsey Institute analysis of $2007 \& 2010$ ASEC data; not shown.

9. Carsey Institute analysis of $2007 \& 2010$ ASEC data; not shown

10. In this brief, "with children" refers to respondents' own children under age six. Though WIC regulations limit receipt to children under five, the data do not allow for this distinction here.

11. In this brief, "single" refers to respondents who are unmarried and non-cohabiting.

12. Zoë Neuberger and Robert Greenstein, "House WIC Cuts Would End Food Assistance for 300,000 to 450,000 Low-Income Women and Children," June 23 Memo (Washington, DC: Center on Budget and Policy Priorities, 2011). Available at http://www.cbpp.org/files/5-23-11fa.pdf.

13. Food and Nutrition Service, "About WIC: How WIC Helps" (Washington, DC: U.S. Department of Agriculture, 2009). Available at http://www.fns.usda.gov/wic/aboutwic/ howwichelps.htm\#references.

14. Ibid.

15. Food and Nutrition Service, "Frequently Asked Questions about WIC" (Washington, DC: U.S. Department of Agriculture, 2011). Available at http://www.fns.usda.gov/ wic/faqs/faq.htm\#3.

16. Food Research and Action Center, "WIC Directors Survey on Nutrition Services Funds: Report Summary" (Washington, DC: Food Research and Action Center, 2006). Available at http://www.frac.org/WIC/pdf/newfood/repsummary_WIC_directors.pdf.

17. Food and Nutrition Information Center, "Commonly Asked Questions: Smart Nutrition 101” (Washington, DC: U.S. Department of Agriculture, 2011). Available at http://www. nutrition.gov/nal_display/index.php?info_center=11\&tax level=2\&tax_subject=389\&level3_id=0\&level4_id=0\&level5 _ id=0\&topic_id=1679\&\&placement_default $=0$.

\section{ABOUT THE AUTHOR}

Jessica A. Bean is a vulnerable families research associate at the Carsey Institute (Jessica.Bean@unh.edu).

\section{A C K N O W L E D G M E N T S}

The author thanks Beth Mattingly, Curt Grimm, and Amy Sterndale at the Carsey Institute for their thoughtful comments and reviews; Barbara Ray at Hiredpen for editorial assistance; and Laurel Lloyd Earnshaw at the Carsey Institute for her assistance in preparing this brief for publication.

\section{A UNIVERSITY Ail of NEW HAMPSHIRE}

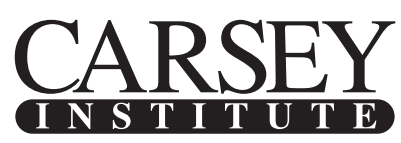

Building knowledge for families and communities

The Carsey Institute conducts policy research on vulnerable children, youth, and families and on sustainable community development. We give policy makers and practitioners timely, independent resources to effect change in their communities.

This work was supported by the Annie E. Casey Foundation, the W. K. Kellogg Foundation, and an anonymous donor.

Huddleston Hall

73 Main Street

Durham, NH 03824

(603) $862-2821$

www.carseyinstitute.unh.edu 